\title{
Remarks on the correlation of tectonic blocks in the foreland of the East European Craton in Poland with those in Ukraine
}

\author{
Włodzimierz MIZERSKI ${ }^{1, *}$, Orest STUPKA ${ }^{2}$ and Izabela OLCZAK-DUSSELDORP ${ }^{1}$ \\ 1 Polish Geological Institute - National Research Institute, Rakowiecka 4, 00-975 Warszawa, Poland \\ 2 National Academy of Sciences of Ukraine, Institute of Geology and Geochemistry of Combustible Materials, Naukova 3a, \\ Lviv 79060, Ukraine
}

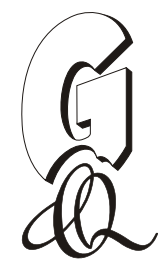

Mizerski, W., Stupka, O., Olczak-Dusseldorp, I., 2016. Remarks on the correlation of tectonic blocks in the foreland of the East European Craton in Poland with those in Ukraine. Geological Quarterly, 60 (1): 124-132, doi: 10.7306/gq.1251

\begin{abstract}
According to common interpretations, two narrow crustal blocks are supposed to occur on the southwestern edge or in the foreland of the East European Craton. The first one, bounded to the NE by the Nowe Miasto-Radom-Rava Ruska fault system, and to the SW by the Holy Cross Fault ( Łysogóry-Rava Ruska Block), stretches NW-SE from the Łysogóry-Radom region in Poland to the Rava Ruska Unit in Ukraine. The second one, bounded to the NE by the Holy Cross Fault, and to the SW by the Chmielnik-Ryszkowa Wola-Krakovets fault zone (Kielce-Kokhanivka Block), is thought to tie together the Kielce area of the Holy Cross region with the Kokhanivka Unit in Ukraine. Both these blocks may have formed in connection with the development of regional listric faults during Precambrian asymmetric stretching of the Baltica continent, and were part of the marginal zone of the East European Craton. The sedimentary development of the blocks may be comparable to that of the Blake Plateau off the Florida coast. Both the Paleozoic sections and tectonic deformation styles in the Polish and Ukrainian segments of these blocks are different. Paleozoic tectonic structures of the Holy Cross region, and in particular its part comprising the Łysogóry Region, have a southern vergence, while the Paleozoic rocks of the Rava Ruska and Kokhanivka units in western Ukraine are thrust along flat thrust surfaces towards the NE. This demonstrates the different tectonic evolution of the Paleozoic succession between the Holy Cross region and western Ukraine, and makes questionable the genetic relationships between these two regions. In this situation, the tectonic blocks of the foreland should be considered heterogeneous. On the other hand, these differences can indicate a different mechanism of tectonic deformation during Variscan movements in both these areas, induced by the same sub-meridional compression of the northward-thrusting Variscan orogen of Europe. Structural-facies evidence suggests that the SW boundary of the East European Craton should be moved at least to the Chmielnik-Ryszkowa Wola-Krakovets fault zone.
\end{abstract}

Key words: marginal part of the East European Craton, Holy Cross Mts., western Ukraine, tectonics, opposite vergence, geotectonic evolution.

\section{INTRODUCTION}

Recently, a number of regional contributions have been published concerning the correlation between tectonic blocks in the foreland of the East European Craton in Poland and Ukraine (Pharoah, 1999; Pharoah et al., 2006; Ziegler and Dézes, 2006; Olczon et al., 2007; Buła et al., 2008; Buła and Habryn, 2011; Jachowicz-Zdanowska, 2011; Żelaźniewicz et al., 2011). According to the interpretations of Buła et al. (2008) and Buła and Habryn (2011), two narrow crustal blocks occur in the southwestern foreland of the East European Craton (Fig. 1). The first one, bounded to the NE by the Nowe Miasto-Radom-Rava Ruska fault system, and to the SW by the Holy Cross Fault (Łysogóry-Rava Ruska Block), stretches

* Corresponding author, e-mail: wlodzimierz.mizerski@pgi.gov.pl

Received: May 8, 2015; accepted: September 7, 2015; first published online: September 16, 2015
NW-SE from the Łysogóry-Radom region in Poland to the Rava Ruska Unit in Ukraine, directly adjoining the East European Craton along the T-T line. The second one, bounded to the NE by the Holy Cross Fault, and to the SW by the Chmielnik-Ryszkowa Wola-Krakovets fault zone (Kielce-Kokhanivka Block), is thought to tie together the Kielce area of the Holy Cross region with the Kokhanivka Unit.

Both these suggested blocks, with a width of 20-50 km each, are easily visible on the sub-Mesozoic surface (Buła and Habryn, 2011: fig. 2). Both of them also show a continuity of Paleozoic outcrops of different ages between the Polish and Ukrainian parts of the blocks. The essential feature distinguishing the Łysogóry-Radom-Rava Ruska Block from the Kielce-Kokhanivka Block is the occurrence of both older and younger Paleozoic rocks in the former, with a continuous Silurian/Devonian transition.

The existence of these blocks seems to be well-documented in both the Polish and Ukrainian territories. The principal problem is the relation of the blocks to the East European Craton. For a long time, Mizerski $(1988,1995)$ has proposed that the Łysogóry area (northern part of the Holy Cross Mts.), 


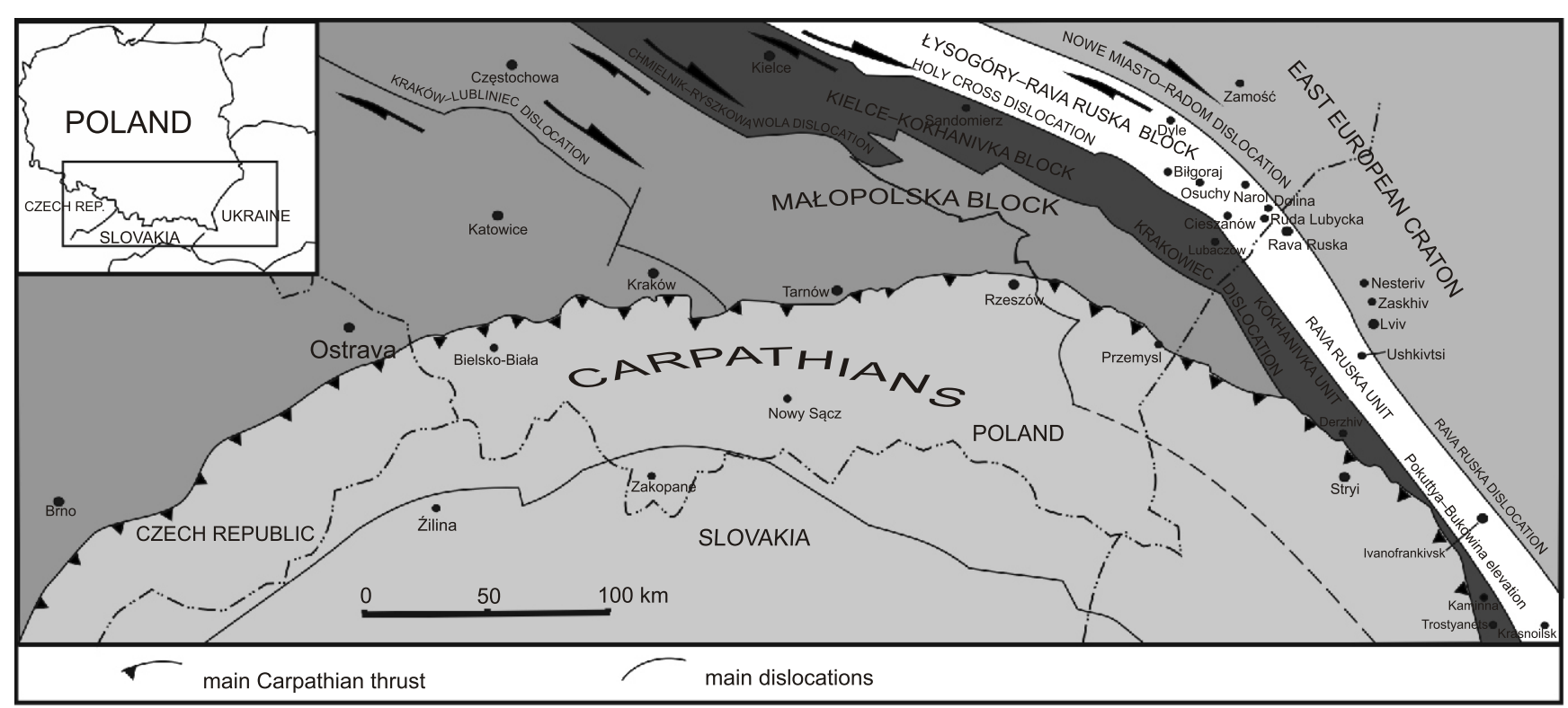

Fig. 1. Tectonic sketch map of crustal blocks in the area north of the major Carpathian thrust front (after Buła and Habryn, 2011 - modified)

Arrows illustrate relative horizontal displacement of crustal blocks along fracture zones

and the Radom-Łysogóry area in a broader sense, can be treated as a down-dropped part of the East European Craton. This view has gained considerable support in the papers by Jaworowski and Sikorska (2005, 2006), who argued that the Cambrian sedimentation, not only in the Łysogóry area but also in the Kielce area (southern part of the Holy Cross Mts.), occurred on the passive margin of the East European Craton. Evidence for this includes Cambrian trilobites (Żylińska, 2002) and the age of the detrital material in the Cambrian rocks of the northern part of Holy Cross Mts (Belka et al., 2000). This view has been supported by Żelaźniewicz et al. (2009) who proposed that the whole Holy Cross region as far as the Kraków-Lubliniec Fault Zone is an area located within the basement of the Baltica continent, in its marginal part. It is also supported by palaeomagnetic studies of the Cambrian and Silurian rocks in the Holy Cross Mts. (Nawrocki et al., 2007).

Both of the blocks discussed, that continue towards the south-east to the southern Lublin region, are supposed to have formed in connection with the development of regional listric faults during Precambrian asymmetrical stretching of the Baltica continent (Jaworowski and Sikorska, 2005, 2006).

The view of the relationship between both the suggested blocks and the East European Craton within the area of Poland is also maintained in the papers by, among others, Olczon (2006) and Olczon et al. (2007), in which the whole Małopolska region and Brunovistulicum are considered as elements originating from the Baltica continent, although separated from it by the Gondwanan terrane extending along the entire edge of the East European Craton in Poland, accreted to in Ordovician and Silurian times. However, the Polish parts of both blocks do not continue into West Ukraine in these papers. Kalvoda (2001) considered that both Brunovistulia and the southern part of the Holy Cross area are Avalonian terranes, and the origin of the Łysogóry Region is unclear. Subsequently, Starostenko et al. (2013) emphasised that the East European Craton in Ukraine extends as far as the main Carpathian overthrust, and its edge lies under the Carpathians.
The aim of this article is to find out whether the existence of these blocks, that extend across Poland and West Ukraine, can be proven in the light of data on the tectonics of the Paleozoic formations of which they are composed.

\section{RELATIONSHIPS BETWEEN \\ THE EAST EUROPEAN CRATON AND THE TECTONIC BLOCKS OF ITS SOUTHWESTERN FORELAND}

Despite relatively abundant geophysical data from the marginal part of the East European Craton (Guterch et al., 1986; Grad et al., 2002; Malinowski et al., 2005; Guterch and Grad, 2006; Narkiewicz et al., 2015), discussions on the relationship of the craton to the blocks of its foreland continue. In tectonic maps, blocks (terranes) of Gondwanan origin are frequently distinguished in the area located west of the T-T line, however, their extent is differently outlined (e.g., Pharoah, 1999; Pharoah et al., 2006; Nawrocki and Poprawa, 2006; Olczon, 2006; Olczon et al., 2007; Żelaźniewicz et al., 2009). This is due to different approaches to the issue of the course of the SW boundary of the craton, referring to the Paleozoic sections in the craton and its foreland (Kraus, 1977; Mizerski, 1988, 1995; Jaworowski and Sikorska, 2005, 2006; Dadlez, 2006; Konon, 2008) and to the tectonic evolution of both areas (Stupka, 1995; Mizerski and Stupka, 2005, 2007; Nawrocki and Poprawa, 2006; Karnkowski, 2008; Narkiewicz and Dadlez, 2008; Żelaźniewicz, 2008; Żelaźniewicz and Aleksandrowski, 2008 Żelaźniewicz et al., 2011; Mizerski et al., 2012, 2014). Most attention has been paid to the Łysogóry-Radom and Kielce regions which are narrow crustal blocks separated by deep fractures interpreted as strike-slip faults (Tomczyk, 1988; Lewandowski, 1993; Jaworowski and Sikorska, 2005, 2006; Buła and Habryn, 2011, Żelaźniewicz et al., 2011), but certainly dip-slip in nature, and at least oblique-slip during the Variscan 
activation (Mizerski, 1979, 1988, 1995). The Paleozoic succession of the Holy Cross region shows close analogies with that of the East European Craton, so that the crustal elements, upon which it is developed, should be treated as marginal parts of the craton, as presented in Żelaźniewicz et al. (2009). Interestingly, the Łysogóry part of the Holy Cross Mts. was called a terrane by Narkiewicz et al. (2015), even though those authors provided a geological section (Narkiewicz et al., 2015: fig. 8) clearly showing that the Łysogóry area is a continuation of the East European Craton.

According to recent interpretations (Buła et al., 2008; Buła and Habryn, 2011), the southwestern boundary of the East European Craton in Poland and Ukraine coincides with the Nowe Miasto-Radom Fault that continues into the Rava Ruska Fault. However, if we follow the views of Mizerski $(1988,1995)$ and Jaworowski and Sikorska $(2005,2006)$, then this fault could not be regarded as the SW boundary of the East European Craton, but only as one of the intracratonic faults in the marginal part of the craton, maybe parallel to the boundary. This fault was similarly interpreted by Żelaźniewicz et al. (2011), who were of the opinion that it runs across the marginal part of the craton, and the surface boundary of the craton is the Skrzynno Fault (Żelaźniewicz et al., 2011: fig. 8).

Even if we assume that there were significant strike-slip movements along the faults bounding the craton and the blocks, as suggested by Lewandowski (1993) but which does not seem to be conclusively proven (in the marginal part of the craton, between Crimea and Lublin, the Lower Paleozoic sections are definitely different than those in the Holy Cross Mts.), they would occur not in hypothetical exotic terranes (there is no evidence of their collision with the craton) accreted to the craton due to collision, but in marginal elongated craton blocks that were moved towards the WNW and suffered earlier increased subsidence accompanied by deposition of thick sedimentary successions. A comparison with the Blake Plateau off the east coast of Florida, which is located in the marginal zone of the Greenland-North American Craton, may be justified here. Dip-slip faults, previously bounding such down-dropped blocks, could be easily used as strike-slip faults or vice versa in another stress field.

The presence of long crustal blocks in the marginal zone of the East European Craton, along which strike-slip movements occur, is not an unusual phenomenon. Within other continents, such blocks are commonly encountered. The most spectacular area with large listric blocks of continental crust is the area of California.

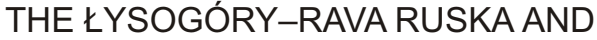 KIELCE-KOKHANIVKA BLOCKS - COMMON FEATURES AND DIFFERENCES BETWEEN THE POLISH AND UKRAINIAN SEGMENTS}

A continuation of the zone of faulted, practically non-metamorphosed rocks of the lower and middle Paleozoic in the Łysogóry and Kielce parts of the Holy Cross Mts can be traced within the Ukrainian Subcarpathians under Jurassic rocks. This is manifested as two highly specific belts extending NW across the Rava Ruska and Kokhanivka units (Rizun and Senkowski, 1973; Stupka, 1986, 1987, 1991, 2002).

The first zone - the Kokhanivka Unit, $25 \mathrm{~km}$ wide and bounded to the south-west by the Krakovets Fault - is composed of a series of black non-calcareous argillites with frequent interbeds of quartzite-like sandstones. Their age is conventionally considered to be Cambrian (Shulga, 1972). In many areas, lithologically similar rocks that were previously assigned to the Jurassic, have recently been included in the Cambrian based on microfossil studies (Jachowicz-Zdanowska, 2011). It is not excluded that, in many areas, the presumed Cambrian rocks that do not contain guide fossils may be in fact of Ediacaran age, since the microfossil assemblages from these rocks as well as their lithological characteristics make them similar to uppermost Precambrian deposits.

These rocks are folded to a different degree - stratal dips in the lower part of borehole sections are low, of the order of $10-20^{\circ}$; while in the upper part, they are commonly $60-90^{\circ}$. The rocks contain numerous fractures filled with vein quartz, anhydrite and calcite, in places heavily crumbled and comminuted. An important tectonic feature of the Kokhanivka Unit rocks is the presence of thick sequences of tectonic breccia (e.g., in the Trostyanets-14 borehole: $440 \mathrm{~m}$ more than tectonic breccia consisting of fragments of Cambrian rocks). This suggests very intense processes of displacement of rock blocks. These rocks also include evidence of thrusting. For example, in the Kaminna-15 and Kaminna-16 boreholes, Cambrian rocks have been found above deposits containing a Silurian fauna. They are in contact with the Silurian along a very gently sloping overthrust of high amplitude, whose surface is inclined towards the south-west. Similar overthrusts were found in the Derzhiv 1 and Derzhiv 3 boreholes.

Another zone (12-18 km wide) - the Rava Ruska Unit - is situated to the NE and composed of Silurian dark grey calcareous argillites with fossils. Locally, they gradually pass into detrital Gedinnian clay deposits. They are separated from the Cambrian and Lower Ordovician deposits by a stratigraphic gap. These rocks are strongly folded and fractured and show a network of calcite veins. It is worth noting that calcite is the only material that fills fractures in this zone, while in the Kokhanivka Unit quartz and anhydrite are also present. This may indicate not only different ages of the fracture-fills, but also different origins of juvenile solutions. Stratal dips are of the order of $70-90^{\circ}$. Slickensides are numerous. The northeastern limit of these rocks is the Rava Ruska Fault.

In the area extending from Rava Ruska to Ivanofrankivsk, north-east of the Rava Ruska Fault, there are Carboniferous deposits of the Lviv Foredeep. They overlie rocks of various ages from Cambrian to Early Devonian. These rocks dip generally in a monoclinal manner and form large folds that group in NW-SE-trending belts that continue into the territory of Poland. A characteristic feature of the subsurface structure of the unit, which makes it resembles the Kokhanivka Unit, is the presence of thrusts whose surfaces are inclined towards the SW. These surfaces flatten with depth: the dip angles in the frontal part are around $30-45^{\circ}$, and away from it are $10-20^{\circ}$. The magnitude of folds and the degree of faulting of the rocks decrease to the NE, towards the interior of the craton.

In the marginal, western and most deformed area (dip angles $50-60^{\circ}$ and more) of the Nesteriv-Zashkiv Zone (Vishnyakov et al., 1996; Vyshniakov et al., 2002), the linear folds occur in the form of tectonic slices, highly uplifted and thrust over each other towards the north-east. Towards the NE, the width of the slices gradually increases from 4 to $14 \mathrm{~km}$, while the amplitudes of their mutual displacements decrease. However, in contrast to the Nesteriv-Zashkiv Zone, the folds in the thrust elements do not have "roots" under the overthrusts (Vishnyakov et al., 1966; Vyshniakov et al., 2002). This shows that the overthrusts had been formed prior to the folding of the rocks of the thrust complex, suggesting a thin-skinned type of tectonic deformation in this area. A characteristic feature of the structures is the presence of very well-developed southwestern limbs of the folds, dipping at $15-20^{\circ}$, the steepness of which de- 


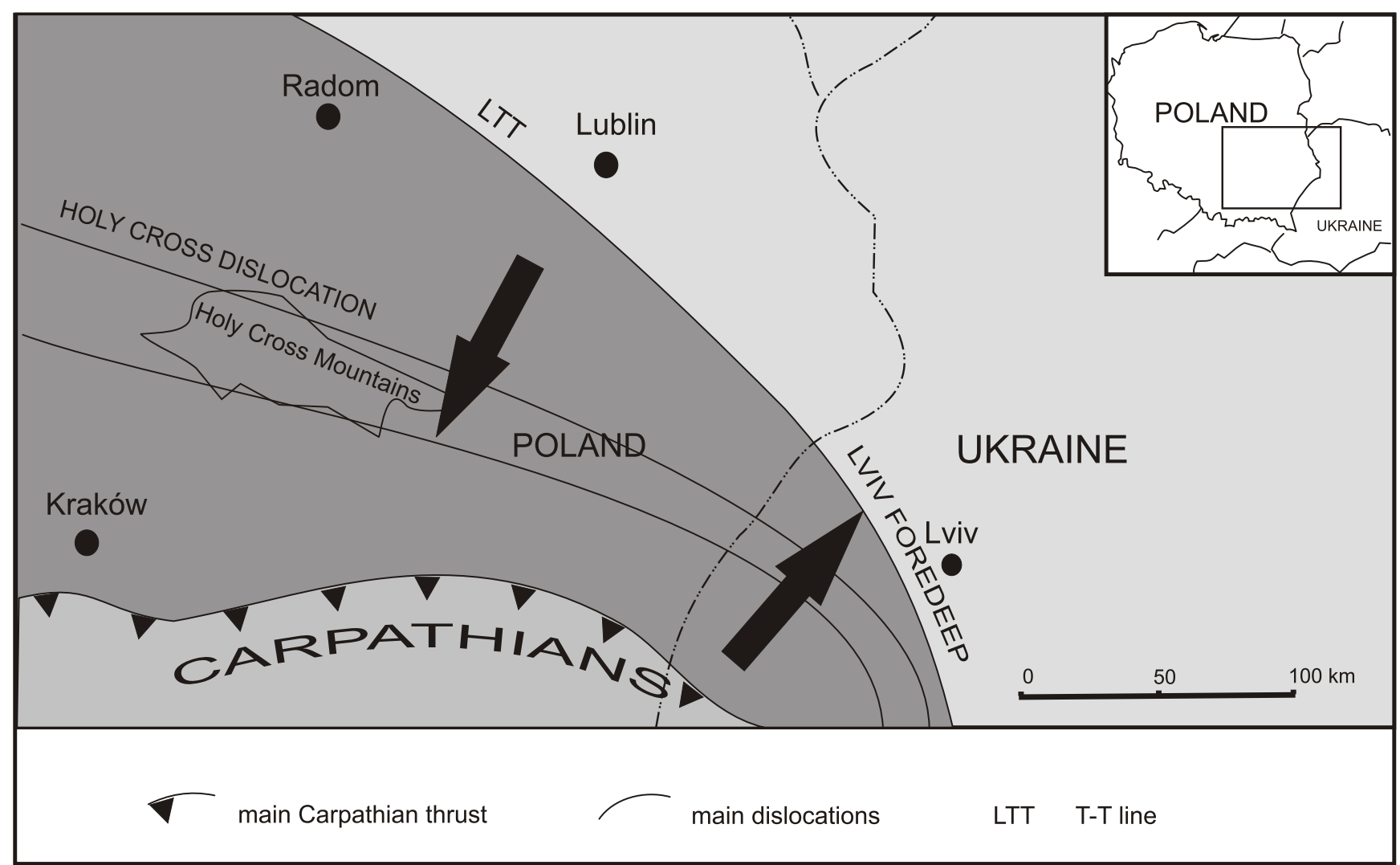

Fig. 2. Vergence of tectonic (thrust, fault and fold) structures in Paleozoic deposits of the Polish and Ukrainian parts of the East European Craton foreland

creases with increasing depth. In contrast, the northeastern limbs are generally poorly developed and many of the overthrusts are accompanied by folding deformation. In the north-east, between Ivanofrankivsk and Krasnoilsk, undeformed and gently westwards-dipping Lower Devonian rocks, underlain by the Silurian, occur to the east of the Rava Ruska Fault (overthrust).

Within the Pokuttya-Bukovina Elevation (Fig. 1), where the pre-Ediacaran basement is notably uplifted and the sedimentary cover is strongly reduced, the folded Paleozoic zone pinches out and appears again only in the NW part of the Black Sea region, where the degree of rock deformation increases towards Dobrogea. Considering the Ukrainian and Polish segments of both blocks, it is striking that the northern block shows continuity between the older and younger Paleozoic rocks, in contrast to the southern block where there is a considerable angular unconformity between the Silurian and younger rocks. This means that the Silurian-Devonian tectonic evolution of the two blocks was different. This difference was most likely due to the activity of the Holy Cross Fault, along which uplift of the Kielce-Kokhanivka Block took place in the Late Silurian, followed by erosion.

The considerable angular unconformity between the older and younger Paleozoic in the Łysogóry part of the Holy Cross Mts., recently suggested by Gągała (2015), cannot cause a change of authors' view that the Caledonian movements did not play a significant role in the Łysogóry area. The long-known phenomenon of uplift of the Łysogóry area at the Silurian/Devonian transition, accompanied by the fault-block tectonic pattern during the uplift of the area, could have resulted in angular unconformities in many places within the lowermost Devonian or at the Silurian/Devonian boundary.
It seems that these are all of the similarities between the Ukrainian and Polish segments of both blocks. Thus, maybe the existence of the two blocks, so clearly visible on the sub-Mesozoic surface (Buła and Habryn, 2011: fig. 2), results not from the facts, but from interpretations. Doubts of this kind may arise from the fact that tectonic deformation styles within the Holy Cross segments of both blocks and their analogues in the Ukraine-Rava Ruska and Kokhanivka units are completely different.

Paleozoic structures of the Holy Cross area are characterized by southwestern vergence (precisely SSW), which has not been questioned (Czarnocki, 1919, 1950; Kowalczewski, 1981; Mizerski, 1988, 1995) and is not controversial, indicating general tectonic transport towards the south (for example Czarnocki, 1950: fig. 13; Konon, 2006: fig. 2). Thrusts and folds that indicate northward tectonic transport occur only in the Lower Cambrian rocks (Mizerski and Skurek-Skurczyńska, 1999; Mizerski, 2004: fig. 3), while the Variscan structures show a northern vergence. In the Ukrainian units the vergence of the structures in the Rava Ruska and Kokhanivka units, as well as in the Lviv Foredeep, is definitely opposite (NE), indicating tectonic transport of both the upper and lower Paleozoic rocks towards the East European Craton (Fig. 2), as suggested by Vishnyakov et al. (1966) and Vyshniakov et al. (2002).

The differences in the tectonic structure become even greater when we consider that, in the Ukrainian foreland of the craton, relatively gently sloping overthrusts are predominant within the Paleozoic formations, along which there are displacements towards the craton (Mizerski and Stupka, 2005: figs. 5 and 6). In contrast, the Holy Cross segments show considerable folding deformation and the accompanying normal and reverse faults are relatively steep. This must be indicative of dif- 
ferent deformation mechanisms between the Holy Cross and Ukrainian parts of both blocks.

Although a geophysical cross-section in Narkiewicz et al. (2015: fig. 8) indicates thrust-like reverse faults in deeper parts of the sedimentary succession of the Łysogóry area, which dip towards the south at a slight angle; however, their existence is not proven. The geological cross-section through the crust at the boundary of the East European Craton and the Paleozoic platform, presented by Gagała (2015), is also thought-provoking. It shows major NE-directed overthrusts in the deeper parts of the crust. If these overthrusts are real, it raises the question why the overthrusts and faults show definitely opposite vergence in the near-surface part of the crust? We consider that conclusions based on facts observed directly in the field are more reliable than those interpreted on the basis of geophysical patterns.

The fact that gently sloping overthrusts are developed in the Rava Ruska and Kokhanivka units promotes the conclusion that tangential tectonic stresses, no matter what their direction was, were probably much stronger there than in the Holy Cross region. This is also indicated by the presence of thick (locally several hundred metres) tectonic breccias which are rare and thin in the Holy Cross region. We can only presume that the effect of the Variscan orogen in the Rava Ruska and Kokhanivka units was significantly greater than in the Holy Cross region. The Variscan orogen front must have run across the area of Ukraine under the present-day Outer Carpathian nappes. It is worth noting that the vergence of tectonic structures in the Ukrainian segment of both blocks is generally consistent with the vergence of Variscan structures (including nappes) of Central Europe, while in the Holy Cross segments, and particularly in the Łysogóry part, the vergence of folds and faults is opposite to the vergence of Variscan orogeny structures. These differences in the tectonic style between the Holy Cross region and the units of Rava Ruska and Kokhanivka must result from a completely different regime and a radically different tectonic stress field in these areas during the Variscan tectonic epoch. It is unlikely that the sedimentary rocks of the same age located on a single small crustal block were subjected to such different deformation patterns at the same time.

However, it cannot be completely precluded that the southern vergence of tectonic structures in the Łysogóry region is a result of the fact that this part of the Holy Cross Paleozoic was uplifted much more strongly, along the Holy Cross Fault which was tilted northwards in the upper part (Mizerski, 1995), than was the Kielce part. As the result, the Paleozoic of the Łysogóry region has been overturned southwards. Then, the currently observed tectonic deformation could be considered as thin-skinned structures with a general tectonic transport direction towards the north, as suggested by Gągała (2015), locating the surfaces of southwards-tilted thrusts in the lower part of the crust of the Holy Cross region. This concept should be tested.

If the fault separating the Rava Ruska Unit from the Kokhanivka Unit is a SE extension of the Holy Cross Fault, then we can attempt to infer its age in the territory of Ukraine. In its SE part, it is evident that Ordovician and Silurian deposits have to lie upon the fault and are not cut by it (Buła and Habryn, 2011: fig. 2). This would mean that this regional crustal fracture was formed in the Cambrian, or even earlier. The unconformity between the Cambrian and Ordovician seems to coincide in age with the Sandomirian orogeny movements. Correspondingly, however, it would imply that this fracture, if it is strike-slip in nature on a regional scale, was active along its entire length at most to and including the Cambrian. Later, different sectors of the fracture may have been subjected to reactivation resulting in the formation of continuous and discontinuous deformation.
However, it should then be assumed that this reactivation occurred only in the Holy Cross segment of the fault. So it is seen that the Variscan fold structures of the Kielce area are arranged diagonally to the Holy Cross Fault. In the territory of Ukraine, there is no indication that the fault was active after the Cambrian.

Knowledge of the degree of tectonic deformation of the Rava Ruska and Kokhanivka units in Ukraine is much poorer than in the Holy Cross region due to limited access to Paleozoic rocks. Therefore, any comparison of their geological structure and evolution cannot provide reliable results. However, reliable results can be obtained by comparing the rocks from Ukraine with the Paleozoic rocks examined by drilling in the Polish area located adjacent to the border with Ukraine (Dyle IG 1, Osuchy, Narol and Dolina boreholes). These boreholes were drilled in the narrow block of Łysogóry-Rava Ruska. The rocks in the Ukrainian part of the block are seen to be highly tectonized, contain numerous slickensides, and their dip angles are approximately $70-90^{\circ}$. In the western part of the Rava Ruska Unit, there are stacked folds that are thrust over each other (Vishnyakov et al., 1966; Vyshniakov et al., 2002). This means that the Rava Ruska Unit can be compared in terms of intensity of deformation with the Łysogóry Region of the Holy Cross Mts., if the vergence of fold, fault and thrust structures was not completely different. However, is that evidence of tectonic similarity of the entire elongated crustal block? Perhaps, but this is doubtful. In the Ruda Lubycka 1 borehole, located on the NE extension of the Rava Ruska Unit, there are Ordovician strata dipping at 10 to $90^{\circ}$. On the other hand, the borehole is located in the immediate proximity to the Nowe Miasto-Radom-Rava Ruska fault zone, which can affect the degree of tectonic deformation of these deposits.

On the other hand, in the Narol borehole, Cambrian, Ordovician and Silurian rocks lie in horizontal and subhorizontal position. In the Ordovician and Cambrian rocks there are weakly inclined overthrusts, but the directions of these overthrusts are unknown (Grelewicz et al., 2014). In contrast, Cambrian rocks of the Dyle borehole, situated NW of the Narol borehole (Fig. 1) in the same block are intensely folded, with numerous normal and reverse faults and cleavage (Kaczmarczyk et al., 2014). This shows that that there are rapidly changing modifications of tectonic structures and styles in the Paleozoic rocks along the SW border of the East European Craton.

The relationships between the Ukrainian and the Holy Cross segments of the Kielce-Kokhanivka Block are also unclear. Can it be treated as a single element? The data available so far seem to contradict this. This is shown by tectonic observations made on the alleged NW extension of the Kokhanivka Unit in the territory of Poland. The degree of tectonic deformation of Ordovician epicontinental deposits in boreholes from the Uszkowice-Cieszanów area is low. Karnkowski (1974) wrote that "...deformation in the form of folds has nowhere been observed in these deposits...". So why is the degree of deformation in these two directly adjacent areas so different?

Interesting results on the correlation of Ordovician deposits with coeval rocks of neighbouring areas are presented in Drygant et al. (2006). Whereas there are clear similarities in the sections and evolution of the Ordovician basin between the Łysogóry area and the Biłgoraj-Narol area, the Ordovician of the Biłgoraj-Narol area shows no similarity to the Ordovician in the Carpathian Foredeep basement of Ukraine and in the Lviv Foredeep. In both the Łysogóry area and the Biłgoraj-Narol zone, there are stratigraphic gaps of variable extent, spanning the Arenigian and Llanvirnian. However, the Carpathian Foredeep basement and the Lviv Foredeep show a continuous Ordovician succession up to the Lower Caradocian. 
While the Upper Ordovician of the Łysogóry and the Biłgoraj-Narol areas is almost complete, this period in eastern Ukraine corresponds to a stratigraphic gap. It would seem that the Ordovician of the Biłgoraj-Narol area should exhibit more similarities to the Ordovician of western Ukraine than to that of the Łysogóry area, but the situation is quite opposite. This may suggest that the Ordovician evolution of the Bitgoraj-Narol area took place under other tectonic-facies conditions than that of the western Ukraine.

Drygant (2000) proposed a lithostratigraphic scheme of Paleozoic rocks in the basement of the marginal part of the Outer Carpathians and the Carpathian Foredeep in western Ukraine, based mainly on lithological criteria and results of several boreholes that suggest the presence of Ordovician and Cambrian rocks. Unfortunately, these rocks in most of the boreholes do not contain fossils and their stratigraphic position has been determined on the basis of a few findings of acritarchs. Drygant (2000) identified Cambrian rocks mainly under a cover of Ordovician clastic deposits without fossils. The successions which are considered Cambrian in age are represented by mudstones, clay shales and quartz sandstones (quartzites), alternating at various proportions. These rocks locally contain trace fossils. Drygant (2000) divided the Cambrian section into three lithostratigraphic units, naming them as follows: Lower Cambrian Baltic Series, reaching a thickness of $132 \mathrm{~m}$; Lower Cambrian Berezhtsi Series, $306 \mathrm{~m}$ thick, and Middle-Upper Cambrian Stryvigor Series that does not exceed $98 \mathrm{~m}$ in thickness. He subdivided these series into 14 lower-order lithostratigraphic units.

Lithologies of Cambrian rocks in the Polish and Ukrainian segments of both blocks are very similar. However, the thick- ness of the Cambrian succession in the Holy Cross region is several times greater than in western Ukraine.

The views of Drygant (2000) have been questioned for several reasons. Firstly, the unfossiliferous Cambrian and Ordovician clastic rocks have been subdivided in most of the boreholes solely on the basis of lithological criteria. It turned out that Drygant (2000) included even Jurassic clastic rocks into the Cambrian and Ordovician succession; while other rocks, considered Jurassic by him, proved to be Cambrian. The palynological studies of Jachowicz-Zdanowska (2011) have allowed precise dating of the rocks.

It seems interesting to compare stratigraphic sections from the Polish and Ukrainian part of the two blocks (Fig. 3). Although the correlation between the Holy Cross region and the Narol area in the Polish territory seems simple and easy to interpret, the correlation between the Polish and Ukrainian parts of the blocks is problematic.

In the tectonic schemes of the SW marginal zone of the East European Craton, the above-described two zones are traditionally treated (although there is no direct evidence) as separate zones of Caledonian consolidation, which were the basement for the young Paleozoic platform of Western and Central Europe. The boundary of the craton is drawn along different fracture zones of Radekhiv, Ustylug-Rogatynsk, Rava Ruska, Krakovets, Fore-Carpathian, and others. If we analyse the reliability of each of these variants, attention should be paid to the fact that only one feature, out of the specific sum of data on the position of the boundary fracture zone, is usually quoted while discussing the issue. This can be a belt of high gravity gradients or a chain of negative gravity anomalies, a zone of rapid change in the magnetic field or a strong lowering

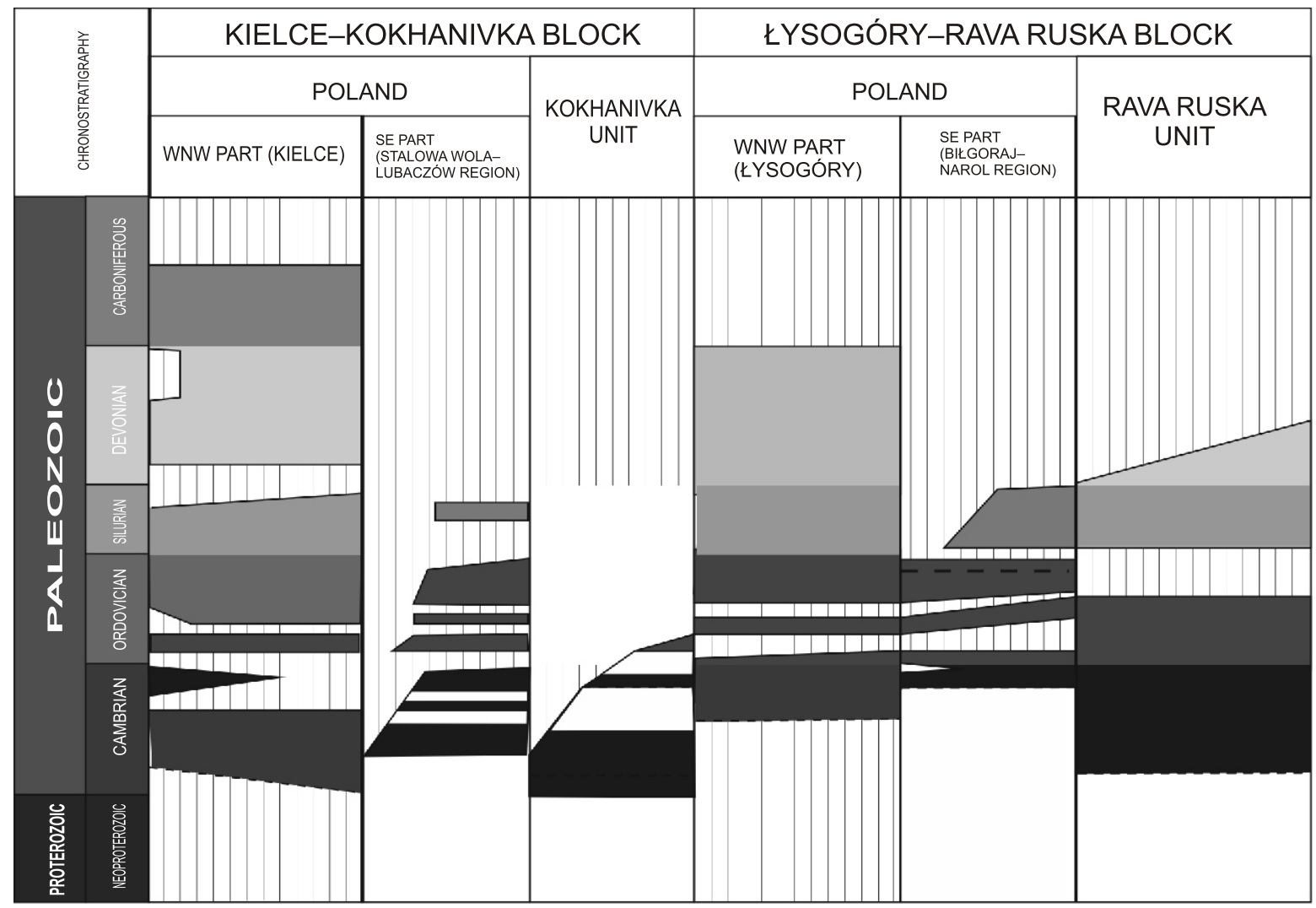

Fig. 3. Correlation of lithostratigraphic sections of Paleozoic deposits in the Holy Cross region, eastern part of the Polish Carpathian Foredeep, and western Ukraine (after Buła and Habryn, 2011 - modified) 
of the basement surface, strong deformation of the sedimentary cover or its facies changes. Despite such diversity, each of these variants is accepted by researchers as a possible SE extension of the T-T line.

The T-T line is traditionally considered a synonym of the SW boundary of the East European Craton. However, recent papers argue that this is a zone, not a line, with a width of 20 to $150 \mathrm{~km}$. The boundary line of the occurrence of magnetic anomalies typical of the pre-Ediacaran basement of the East European Craton does not coincide with the T-T line, but is located much further towards the SW. It should be emphasized that this line is very poorly visible in space images, although the Warta and Elbe lines can be deciphered very clearly (Bush et al., 1978; Khain et al., 1979). In addition, in the area between the T-T line and the Elbe line, there is a clearly traceable pattern corresponding to the structure of the East European Craton. Air images show that it is cut by a series of faults (Bush et al., 1978).

\section{CONCLUSIONS}

The presence of elongated crustal blocks along the SW edge of the East European Craton seems to be well-documented both in the area of Poland and Ukraine. These blocks, depending on the viewpoint, may be considered either down-dropped epicratonic blocks, or proximal terranes showing a close relationship with the East European Craton throughout Phanerozoic times. However, the listric blocks, so defined along the SW edge of the East European Craton, are inhomogeneous and characterized by a diverse geotectonic development along their extent. It is curious that the changes in geotectonic regime are manifested near the border between Poland and Ukraine.

These differences permit two different, indeed opposing conclusions to be drawn:

1. The elongated blocks of the craton foreland can be considered an epicratonic zone;
2. Between the Rava Ruska and Kokhanivka zones and the Radom-Łysogóry and Kielce blocks, there is a yet-undiscovered discontinuity zone where the change in geotectonic regime occurs.

According to the present authors, the true edge of the epi-Karelian craton as a single physical body is plunges steeply, in the area located SW of the T-T line, under fold-nappe complexes which were thrust over its margin and formed in close connection with the evolution of the Variscan orogen of Central Europe. The two zones described above can be parts of these complexes.

The main structures defining the tectonic style of these zones are overthrusts, reverse faults, tectonic slices, and a variety of folds, i.e. structures that formed as a result of horizontal compression. This additionally emphasizes the intensity of rock deformation expressed by numerous and significant changes in stratal dips in vertical section, numerous slickensides, brecciation, fissility and other signs of displacement of rock masses as a result of tangential stresses.

Signs of horizontal stress are observed in the structures that reflect the regional pattern of middle and lower Paleozoic rocks, represented by zones of anticlinal folds. They are conspicuous by a clearly marked linearity (their axes are oriented parallel to the edge of the East European Craton), a compressed and commonly asymmetrical cross-section, and a northward to north-east overturning.

It is therefore necessary to continue the research carried out using a similar methodology to study the continuity of crustal blocks in the SW foreland of the East European Craton in both Poland and Ukraine. This can significantly contribute to explain the course of the southwestern edge of the East European Craton and, indirectly, to determine the processes of accretion of the Baltica continent with blocks of other provenance.

Acknowledgments. We thank T. Peryt for helpful discussion as well as the reviewer A. Seghedi and an anonymous reviever for constructive comments on the manuscript.

\section{REFERENCES}

Belka, Z., Ahrendt, H., Franke, W., Wemmer, K., 2000. The Baltica-Gondwana suture in central Europe: evidence from K-Ar ages of detrital muscovites and biogeographical data. Geological Society Special Publications, 179: 87-102.

Buła, J., Habryn, R., 2011. Precambrian and Palaeozoic basement of the Carpathian Foredeep and the adjacent Outer Carpathians (SE Poland and western Ukraine). Annales Societatis Geologorum Poloniae, 81: 221-239.

Buła, Z., Żaba, J., Habryn, R., 2008. Tectonic subdivision of Poland: southern Poland (Upper Silesian Block and Małopolska Block (in Polish with English summary). Przegląd Geologiczny, 56: 912-921.

Bush, W.A., Garecki, R.G., Kiryuhin, L.G., 1978. K tektonikie Srednieevropeisoj plity i iee obramlenyi po danym deshifrovania kosmicheskikh snimkov (in Russian). Doklady Akademi Nauk SSSR, 239: 146-149.

Czarnocki, J., 1919. Stratigraphy and tectonics of the Holy Cross Mts. Prace Towarzystwa Naukowego Warszawskiego, 28: $1-172$.

Czarnocki, J., 1950. Geology of the Łysa Góra region (Święty Krzyż Mountains) in connection with the problem of iron ores at Rudki (in Polish with English summary). Prace Państwowego Instytutu Geologicznego, 6a.

Dadlez, R., 2006. The Polish Basin - relationship between the crystalline, consolidated and sedimentary crust. Geological Quarterly, 50 (1): 43-58.

Drygant, D.M., 2000. Lower and Middle Palaeozoic of the Volyn Podollya margin of the East-European Platform and Carpathian Foredeep (in Ukrainian with English summary). Naukovi zapiski Derzhavnogo prirodoznavchego muzeyu, 15: 24-130.

Drygant, D.M., Modliński, Z., Szymański, B., 2006 Lithostratigraphical correlation of the Ordovician in the Biłgoraj-Narol area with deposits of the adjacent regions of the marginal zone of the East European Craton in Poland and Ukraine (in Polish with English summary). Przegląd Geologiczny, 54: 219-227.

Gągała, Ł., 2015. Late Silurian deformation in the Łysogóry Region of the Holy Cross Mountains revisited: restoration of a progressive Caledonian unconformity in the Klonów Anticline and its implications for the kinematics of the Holy Cross Fault (Central Poland). Geological Quarterly, 59 (3): 441-456.

Grad, M., Guterch, A., Mazur, S., 2002. Seismic refraction evidence for crustal structure in the central part of the Trans-Euro- 
pean Suture Zone in Poland. Geological Society Special Publications, 201: 295-309.

Grelewicz, M., Kaczmarczyk, J. Żaba, J., 2014. Cechy strukturalne utworów fanerozoiku w otworze Narol IG-1 - SW strefa krawędziowa kratonu wschodnioeuropejskiego (in Polish). In: Wyzwania geologii regionu lubelskiego w XXI wieku (ed. W. Mizerski): 15. Państwowy Instytut Geologiczny, Warszawa.

Guterch, A., Grad, M., 2006. Lithospheric structure of the TESZ in Poland based on modern seismic experiments. Geological Quarterly, 50 (1) 23-32.

Guterch, A., Grad, M., Materzok, R., Perchuć, E., 1986. Deep structure of the Earth's Crust in the Contact Zone of the Palaeozoic and Precambrian Platforms in Poland. Tectonophysics, 128: 251-279.

Jachowicz-Zdanowska, M., 2011. Cambrian organic microfossils at the border area of the East- and West-European platforms (SE Poland and western Ukraine). Annales Societatis Geologorum Poloniae, 81: 241-267.

Jaworowski, K., Sikorska M., 2005. Związek jednostki łysogórskiej z kratonem wschodnioeuropejskim na tle badan sedymentologiczno-petrograficznych osadów kambru (in Polish). Posiedzenia Państwowego Instytutu Geologicznego, 61 13-15.

Jaworowski, K., Sikorska, M., 2006. Łysogóry Unit (Central Poland) versus East European Craton - application of sedimentological data from Cambrian sillicoclastic association. Geological Quarterly, 50 (1): 77-88.

Kaczmarczyk, J., Grelewicz, M., Żaba, J., 2014. Styl deformacji utworów kambryjskich w otworze wiertniczym Dyle IG-1 brzeżna strefa kratonu wschodnioeuropejskiego (in Polish). In Wyzwania geologii regionu lubelskiego w XXI wieku (ed. W. Mizerski): 20. Państwowy Instytut Geologiczny, Warszawa.

Kalvoda, J., 2001. Upper Devonian-Lower Carboniferous foraminiferal paleobiogeography and Perigondwana terranes at the Baltica-Gondwana interface. Geologica Carpathica, 52 205-215.

Karnkowski, P., 1974. Zapadlisko przedkarpackie - Część wschodnia (na wschód od Krakowa) (in Polish). In: Budowa geologiczna Polski. Tom IV (1) Tektonika, Niż Polski (ed. W. Pożaryski): 402-416. Wyd. Geol., Warszawa.

Karnkowski, P.H., 2008. Tectonic subdivision of Poland: Polish Lowlands (in Polish with English summary). Przegląd Geologiczny, 56: 895-903.

Khain, E.W., Pietrenko, W.S., Kutek, J., Trofimov, D.M., Kac, J.G., 1979. K voprosu o sokhlenienii Russkoi srednieevropeisoi plit (in Russian). Vestnik Moskovskogo Gosudarstviennogo Universiteta, seria geologia, 2: 27-32.

Konon A., 2006. Młodopaleozoiczna ewolucja strukturalna Gór Świętokrzyskich (in Polish). In: LXXVII Zjazd Naukowy Polskiego Towarzystwa Geologicznego, Warszawa (eds. S. Skompski and A. Żylińska): 82-104. Państwowy Instytut Geologiczny, Warszawa

Konon, A., 2008. Tectonic subdivision of Poland: Holy Cross Mountains and adjacent areas (in Polish with English summary). Przegląd Geologiczny, 56: 921-927.

Kowalczewski, Z., 1981. Major problems of the tectonics of Paleozoic cockle ion the Holy Cross Mts (in Polish with English summary). Przegląd Geologiczny, 31: 334-340.

Krauss, M., 1977. Zur Mobilität tektonischer Einheiten des westlichen Teils der Osteuropäischen Plattform. Wissenschaftliche Zeitschrift der Ernst-Moritz-Arndt Universität Greifswald, 26: 106-118.

Lewandowski, M., 1993. Paleomagnetic data from the Early Devonian sandstones of the Holy Cross Mts and their geotectonic implications. Publications Institute of Geophysics Polish Academy of Sciences, A-19 (236): 131-150.

Malinowski, M., Żelaźniewicz, A., Grad, M., Guterch, A., Janik, T., 2005. Seismic and geological structure of the crust in the transition from Baltica to Palaeozoic Europe in SE Poland -
CELEBRATION 2000 experiment, profile CEL02. Tectonophysics, 401: 55-77.

Mizerski, W., 1979. Tectonics of the Łysogóry unit in the Holy Cross Mts. Acta Geologica Polonica, 29: 1-38.

Mizerski, W. 1988. Tectonic evolution of the Łysogóry region, Holy Cross Mts (in Polish with English summary). Przegląd Geologiczny, 36: 46-52.

Mizerski, W., 1995. Geotectonic evolution of the Holy Cross Mts in Central Europe. Biuletyn Państwowego Instytutu Geologicznego, 372: 1-47.

Mizerski, W., 2004. Holy Cross Mountains in the Caledonian, Variscan and Alpine cycles - major problems, open questions. Przegląd Geologiczny, 52: 774-779.

Mizerski, W., Skurek-Skurczyńska, K., 1999. Small tectonic structures of the Cambrian rocks in the Middle part of the Klimontów Anticlinorium (Kielce Block, Holy Cross Mts, Central Poland) (in Polish with English summary). Przegląd Geologiczny, 47: 266-272.

Mizerski, W., Stupka, O., 2005. Western and southern extent of the East European Craton (in Polish with English summary). Przegląd Geologiczny, 53: 1030-1039.

Mizerski, W., Stupka, O., 2007. Some remarks on the influence of the foreland structure on the formation of a frontal nappe thrust (in Polish with English summary). Przegląd Geologiczny, 55: 430-434.

Mizerski, W., Stupka, O., Olczak-Dusseldorp, I., 2012. Does the East European branch of the Caledonides exist? Biuletyn Państwowego Instytutu Geologicznego, 499: 109-118.

Mizerski, W., Stupka, O., Olczak-Dusseldorp, I., 2014. Korelacja bloków przedpola kratonu wschodnioeuropejskiego w Polsce z blokami przedpola tego kratonu na Ukrainie i jej znaczenie dla poszukiwań gazu łupkowego (in Polish). Abstrakt LXXXIII Zjazdu Naukowego Polskiego Towarzystwa Geologicznego Biała Podlaska, 29-31 maja 2014: 29. Państwowy Instytut Geologiczny, Warszawa.

Narkiewicz, M., Dadlez, R., 2008. Geological regional subdivision of Poland: general guidelines and proposed schemes of sub-Cenozoic and sub-Permian units (in Polish with English summary). Przegląd Geologiczny, 65: 391-397.

Narkiewicz, M., Maksym, A., Malinowski, M., Grad, M., Guterch, A., Petecki, Z., Probulski, J., Janik, T., Majdański, M., Środa, P., Czuba, W., Gaczyński, E., Jankowski, L., 2015. Transcurrent nature of the Teisseyre-Tornquist zone in Central Europe: results of the POLCRUST-01 deep reflection seismic profile. International Journal of Earth Sciences, 104: 775-696.

Nawrocki, J., Poprawa, P., 2006. Development of the Trans-European Suture Zone in Poland: from Ediacarian to Early Palaeozoic accretion. Geological Quarterly, 50 (1): 59-79.

Nawrocki, J., Dunlop, J., Pecskay, Z., Krzemiński, L., Żylińska, A., Fanning, M., Kozłowski, W., Salwa, S., Szczepanik, Z., Trela, W., 2007. Late Neoproterozoic to Early Palaeozoic palaeogeography of the Holy Cross Mountains (Central Europe): an integrated approach. Journal of the Geological Society, 164: 405-423.

Olczon, M., 2006. Terrane Map of Europe. Gaia Heidelbergensis 15, http://www.geobib.uni-hd.de/terranemap/index.html.

Olczon, M., Seghedi, A., Carrigan, C., 2007. Avalonian and Baltican origins terranes in the Moesian Platform (southern Europe, Romania and Bulgaria) in the context of Caledonian terranes along the southwestern margin of the East European craton. GSA Special Paper, 423:375-400.

Pharoah, T.C., 1999. Palaeozoic terranes and their lithospheric boundaries within the Trans-European Suture Zone, TESZ, a review. Tectonophysics, 314: 17-41.

Pharoah, T.C., Winchester, J.A., Verniers, J., Lassen, A., Seghedi, A., 2006. The Western Accretionary Margin of the East European Craton: an overview. Geological Society Memoir, 32: 291-312.

Rizun, B.P., Senkowski, Yu.N., 1973. To the problem of paleotectonic and paleographical reconstructions in folded-sheet areas (in Russian). Geotectonics, 4: 43-79. 
Starostenko, V., Janik, T., Lysynchuk, D., Środa, P., Czuba, W., Kolomiyets, K., Aleksandrowski, P., Gintov, O., Omelchenko, V., Komminaho, K., Guterch, A., Tiira, T., Gryn, D., Legostaeva, O., Thybo, H., Tolkunov, A., 2013. Mesozoic? litosphere-scale buckling of the East European Craton in southern Ukraine: Dobre 4 deep seismic profile. Geophysical Journal International (2013), doi: 10.1093/gji/ggt292.

Stupka, O.S., 1986. Geological evolution and structure of the Earth's crust of the European part of the Soviet Union in Pre-Cambrian time (in Russian with English summary). Naukova Dumka, Kiev.

Stupka, O.S., 1987. Genesis of the Lower-Middle Paleozoic formations of the southern and south-western edge of the Eastern European Platform (in Russian with English summary). Bulletin of the Academy of Sciences of the USSR. Division of Geology, 293: 192-195.

Stupka, O.S., 1991. On tectonic structure of Lower-Middle Paleozoic deposits of the south-western and southern edge of the East European Platform and possible mechanism of its formation (in connection with the problem of oil and gas presence in deep-seated horizons) (in Russian with English summary). Geology and Geochemistry of Combustible Minerals, (77): 13-23.

Stupka, O.S., 1995. On the notion of „platform boundary” (in Ukrainian with English summary). Geology and Geochemistry of Combustible Minerals, (3-4): 41-46.

Stupka, O.S., 2002. Thrust and underthrust structures: new object promising for great deposits of oil and gas within the south-western edge of the East European Platform (in Ukrainian with English summary). In: The problems of oil and gas complex of the Ukraine: 30-40. NIKE-CENTR, Kyiv.

Shulga, P.L., 1972. Stratigrafia USSR. Kembryi-Ordovik (in Russian). Naukova Dumka, Kiev.
Tomczyk, H., 1988. Tectonic movements between margin of the East-European Platform and the Holy Cross Mts region in Paleozoic (in Polish with English summary). Przegląd Geologiczny, 35: 9-17.

Vishnyakov, I.B., Kotyk W.A., Levin G.I., 1966. Structural peculiarities of Lvov Paleozoic trough (in Russian). Geologia Niefty i Gaza, 8: 23-26.

Vyshniakov, I.B., Havrylko, G.A., Honyk, I.O., 2002. Some aspects of prospective structures forecast in the inner zone of Lviv Paleozoic foredeep (in Ukrainian with English summary). Geology and Geochemistry of Combustible Minerals, (3): 14-20.

Ziegler, P., Dézes, P., 2006. Crustal evolution of Western and Central Europe. Geological Society Memoir, 32: 43-56.

Żelaźniewicz, A., 2008. Tectonic subdivision of Poland - state of the art and attempt to revision (in Polish with English summary). Przegląd Geologiczny, 56: 887-994.

Żelaźniewicz, A., Aleksandrowski, P., 2008. Tectonic subdivision of Poland: southwestern Poland (in Polish with English summary). Przegląd Geologiczny, 56: 904-911.

Żelaźniewicz, A., Buła, J., Fanning, M., Seghedi, A., Żaba, J., 2009. More evidence on Neoproterozoic terranes in Southern Poland and southeastern Romania. Geological Quarterly, 53 (1): 93-124.

Żelaźniewicz, A., Aleksandrowski, P., Buła, Z, Karnkowski, P.H., Konon, A., Oszczypko, N., Ślączka, A., Żaba, J., Żytko, K., 2011. Regionalizacja tektoniczna Polski (in Polish). Komitet Nauk Geologicznych PAN, Wrocław.

Żylińska, A., 2002. Stratigraphic and biogeographic significance of Late Cambrian trilobites from Łysogóry (Holy Cross Mountains, central Poland). Acta Geologica Polonica, 52: 217-238. 